Krzysztof Pawlina

Pope's Theology Faculty in Warsaw,

St John the Baptist Section

\title{
JP2 Generation Phenomenon
}

\section{Abstract}

Generally speaking, young people in Poland do not reject religion. The vast majority of youth declare themselves to be believers. Their faith, however, is characterized by subjectivity and selectiveness. Situationism is a trait of the Polish young generation. They make their choices dependent on something... Gaining a good education, a good job and starting a family are important life goals for young people. The youth of the 21 st century are called "the youth without wings". Those young people do not have any great ideals. They are not attracted by high values of a changing the world, they do not aim at establishing a better social system. The youth of the 90's used to set up non-governmental organizations, they took up social activity in the third sector. The young people of the 21 st century comprise a generation focusing on their own future. It is not a struggling generation but rather one evading or minimizing their activity in spheres which do not bring them direct benefits. Whatever is not practical, needed for today, is discarded.

\section{Keywords}

Transformation, John Paul II, life of young people, the generation of unfulfilled hopes, Educational leap, Erosion of the old world, Goals, Religiousness of young Poles, JP2 generation.

\section{Introduction}

Primate Stefan Wyszyński, thinking about the future, once wrote: "A tribe of new people is coming". Times are changing, yet thinking about the future every generation must ask the following question - What will this tribe of new people 
be like? What will this novelty be all about? Let us attempt to characterize these new people - the tribe which has been growing in Poland after the death of John Paul II.

\section{1. „JP2 generation” concept}

The young generation of Poles born after 1989 is called either Generation T, i.e. transformation generation, or Generation None which means too young to get an attractive position, too old to wait for the effects of the system transformation, i.e. none. The young generation is also defined as Generation R. It is an abbreviation for values which young people want to live by. If we wanted to express them in the form of an advertisement slogan it could be " $4 \mathrm{x} \mathrm{R}$ " - rodzina (family), rynek (market), religia (religion), rozsądek (reason). The youth of the Internet era is also called the "Net Generation" or "net kids". These young people are also referred to as the JP2 Generation - they are people for whom John Paul II is the point of reference.

It should be mentioned that it is problematic to define what we mean by a generation.

In the Polish language, we have something called the Columbus Generation. It was introduced after a book by Roman Bratny, "Kolumbowie rocznik 20" (Columbuses born in 1920). It refers to those who were born in an independent Poland, i.e. in the 20s of the 20th century. The period of their adolescence was during the years of World War II. The time of German-Russian captivity ${ }^{1}$ was a milestone for the generation. According to some sociologists these people can be considered as a generation. For the sake of these considerations we can assume a sociological definition that a generation comprises "a group of people having common stances and values which were acquired through participation in historic events constituting a significant element of their life experience".

So how should the JP2 Generation be understood? The JP2 Generation concept was first used during the World Youth Days held in Paris 1997. After the $2^{\text {nd }}$ April 2005, i.e. after John Paul II's death it gained its own dynamism. Anna Radiukiewicz claims that JP2 Generation may cover several age groups. One of them refers to current forty and fifty year olds who were entering their adulthood at the time when Cardinal Karol Wojtyła was elected pope. Another group can be made of thirty year olds who shaped their system of values based on John Paul II's teaching and were frequent participants of the papal pilgrimages

\footnotetext{
${ }^{1}$ T. Worczyński, Literatura polska po 1939 roku, Warszawa 1995, p. 68.
} 
to his motherland. Today's twenty year olds and teenagers who do not remember any other pope than JP2 can be also included in JP2 Generation ${ }^{2}$. Therefore it is difficult to decide unequivocally who makes up the JP2 Generation.

In December 2011, a survey was carried out among the students of St. Anna's Church Student Ministry. The survey included four open questions including the following one: "Do you think that you are the part of the JP2 Generation? Please, justify your answer." The result turned out to be a surprise. About $40 \%$ of students said "the fact that I was born during John Paul II's pontificate does not allow me to consider myself JP2 Generation. Why? Because I do not sufficiently know his teaching." Moreover, those students usually added: "Although I do not know his teaching in depth, I nevertheless love him. He is important in my life".

\section{Religiousness of young Poles}

We are now in a new situation. John Paul II is no longer with us. The novelty of the young generation overlaps the novelty of civilization - transformation from the late industrial society to the information society. In interpersonal relations it means transformation from the real to the virtual. The world is changing. John Paul II died when the old world was coming to an end. In politics and the economy, the period of post-war prosperity is coming to an end. Today, the young face the world without principles or the world of soft principles. Although they learn good examples, when they turn on TV or the internet they see something else.

What is the youth after John Paul II like? Generally speaking the youth in Poland do not reject religion. All kinds of surveys, both nationwide and local, indicate that religion is necessary in a man's life. According to those surveys, religion has an important function, for instance, to make sense of issues or therapeutic functions ${ }^{3}$. Hence, a significant majority of youth declare themselves as believers. However, their faith is subjective, selective or full of doubts. Young people say, for example, I believe in God but I do not believe in hell. I believe in God but I doubt whether Christ was God.

${ }^{2}$ A. Radiukiewicz, Pokolenie JP, tożsamość czy kreacja medialna?, in: JP2 pokolenie czy mozaika wartości?, Warszawa 2010, p. 179-183; A. Draguła, Czy istnieje pokolenie JP2? Projekt: Życie sensem, „Tygodnik Powszechny” No. 24, 16th October, 2005, p. 12; T. Sawicka, Pokolenie JP2. Przeszłość i przyszłość zjawiska religijnego, Warszawa 2008, p. 90-140.

3 R. Dolata, K. Kosela, A. Wiłkomirska, A. Zielińska, Młodzi obywatele. Wyniki międzynarodowych badań młodzieży, Warszawa 2004, p. 29-45; D. Walczak-Duraj, Wartości i postawy młodzieży polskiej, Łódź 2009, K. Pawlina, Młodzież szkolna o swoich problemach, Warszawa 2010. 


\section{The Person and the Challenges \\ 138

Speaking of moral aspects of life, young people reluctantly accept moral principles taught by the Church. Such a stance is most visible in reference to aspects of premarital life. Young people feel more like "creators" than addressees of moral norms. In their behaviour they are often guided by the principle of "because I like it", "because it is convenient for me".

It is different when abortion is concerned. Life in the eyes of the young generation still has great value. So even though young people reject the teachings of the Church regarding sexual life the number of young people against abortion has increased.

Generally speaking, young people do not allow any interference in moral issues whatsoever. Nobody will tell me what I should do - they say.

Another feature of the young generation is situationism. It means that young people, when asked about moral judgment, reply: "It depends on the situation". There is therefore nothing stable, everything depends on something.

With regard to religious practices, a new phenomenon can be seen - religious spontaneity. If something big happens young people leave their homes and go on a pilgrimage or to a concert in memory of John Paul II. And afterwards they hide again in their own lives. They have difficulty with regular practices.

How do young people live their faith?

In Poland, faith was a national and cultural value for many years. Faith was an inherited value passed along at home and within the nation as something obvious, as a social value.

Sociological diagnoses tell us something about changes in religiousness ${ }^{4}$. They do not predict a fall of religiousness in Poland in the future. They say however about changes. This change consists of a transformation from the religiousness which has been inherited to the lived one. Religiousness is no longer a traditional value and becomes a personal experience. It means that if someone was born in a family of believers, the faith is not automatically shared with them. Today, a man wants to decide himself. In short, a sudden turning away from religion is not being anticipated but it is predicted that it will no longer be passed, as it used to be, by tradition but it will be more a matter of personal choice. They do not want anything imposed. A conscious personal decision is the future direction for believers.

Many young people seek stronger and stronger spiritual experiences. It is not unjustified to say that there is a growing number of young people who treat religion as a TV set with a remote control. As long as it gives the feeling of

\footnotetext{
${ }^{4}$ K. Pawlina, Młodzież szkolna o swoich problemach, Warszawa 2010, p. 37-45.
} 
excitement I stick to it. When it starts to demand prayer according to the rhythm of a liturgical calendar, I switch off.

For them, emotions and spiritual sensations are a product and the Church is a shop with a specific spiritual offer. They are looking for adventure even in what is spiritual.

There is still $5 \%$ of young people related to movements within the Church. They live a life on a different level. There are also young people who are looking for depth. Retreat houses and monasteries receiving guests for a few days' stay are full. For Ignatian retreats you need to enrol several months in advance. There are many people who from time to time spend a night in prayer rather than go to a discotheque. Nobody knows how many they are. It is important that they are like springs in a desert.

One cannot see any flourishing of oriental cults. These movements invaded Poland in the second half of the $70 \mathrm{~s}$. In the 80 s they began to grow fast. It seemed that they were spreading and would become an alternative for those seeking spirituality.

In the late 90 s some of them remained established while others even withdrew.

\section{Young people's goals}

What are the life goals of the young generation? The family is still in the top ranks of the life goals. However, the traditional family model has been questioned. Marriage has changed into an informal relationship. Young people believe that marriage is a limited liability company. When it fails you start another one. This is confirmed by the most recent studies revealing growing liberalization of attitudes regarding the institution of marriage. In young people's imagination, marriage appears as a soft institution adapting rather to the partners' individual needs and expectations than social functions and requirements. A relationship is created out of the need of the heart. It ends when the heart has other needs. The same young people when asked about their dreams say: I would like to have a happy family and to be loved. Young people's expectations do not overlap with their actions.

There is also a danger of delayed adulthood. Generally, the age at which people get married has been changing. According to the Main Statistical Office, the age of newlyweds has increased considerably.

Getting a good education is an important life goal for the young generation. Education is the key to three very important spheres of life and three kinds 
of needs: security, level and quality of life and prestige. However, education, very highly appreciated by young people in recent years, has been losing its importance. Although it increases the chances of a better life it does not guarantee success. Some young people start to notice that it does not make sense to follow over-ambitious educational ideas. Getting a diploma for its own sake, educational offers not matching the requirements of the labour market, unemployment among high school graduates, effort and cost related with education - all these influence changes in educational preferences. One can observe a "cooling down" of the educational aspiration level. Vocational training, shorter and not requiring too much investment, has been becoming more popular.

Until recently, studies indicated that young people were enchanted by extraordinarily colourful life models and a wish to have exceptional careers. Faced with reality and an uncertain future, a quiet option is emerging, aimed at a peaceful and secure life. The pillars of this option are: stable employment and good, warm relations with close family and friends.

The necessity of going abroad as the best solution for young people has weakened. Emigration is no longer such an attractive prospect for young people as it used to be only four years ago.

The young people of the beginning of the 21 st century are called "youth without wings". They do not have big ideals. They are not attracted by great values changing the world; they do not try to establish a different, better social system. Young people of the $90 \mathrm{~s}$ were creating non-governmental organizations and were undertaking social activities in the third sector. The youth in the beginning of the 21 st century is a generation which concentrates on its own future.

It is not a struggling generation but rather the one minimizing activity in the spheres which do not bring direct benefits to them. What is not practical - needed for today - is dismissed as something for the future ${ }^{5}$.

\section{Young people still at a turning point}

Erosion of the old world.

Polish youth still lives in the world of their grandparents' and parents' values. If we ask how the young generation identifies itself, their social "soul" is made up of the following values: I am part of my family, I am a Pole, I am a Catholic.

Although they speak of traditional values, objectively they live in a different world. What world? An unstable world. This instability is created by

\footnotetext{
${ }^{5}$ M. Boni (ed.), Jacy sq młodzi, in: Młodzi 2011, Warszawa 2011, p. 35-61.
} 
unemployment. A job determines life's scenarios - it structures life. Those who were born in the $50 \mathrm{~s}$ or $60 \mathrm{~s}$ knew more or less what their life would be like. Some things could have been predicted: that they would have an apartment at some point in time, which would have a job related to the field of their education and that they would start a family. Their life was to be planned. Those who entered adulthood in the 90 s and later already live in a world where they are no longer sure of stable employment. They already live in the world of flexible jobs. This is the world in which you can plan an evening, to go to a restaurant or a cinema, but it is impossible to plan what my life will like in two years' time. A structured life model has ended. A manager today - in two years' time - may be unemployed. Nowadays young people live in a world of uncertainty. They do not know who they will be.

A changing and uncertain world produces volatile people. A lack of stability discourages them from taking on any obligations, including having a family and having children.

Lack of stability also results from another issue. New professions are created which do not allow stability in life. Jobs which did require even basic skills but were paid enough to afford a flat and starting a family are no longer available. They used to help to in becoming self-sufficient. What jobs for young, less capable people remain? A job at McDonald's, being a messenger or a pizza deliverer. These are the jobs which do not even require social skills. They give you enough to survive but too little to start a family and rent an apartment, to settle down.

Such a world - a changing world - demands of the Church to show what is stable. One needs to show areas on which you can rely on in life - something that never changes although the world changes. A young man will have many places of work in his life but what never changes is God, faithfulness to your wife and family.

Wasted dynamism

Poland currently has the highest number of young people in Europe. A demographic peak of children born in 1982, 1983 and 1984 has become visible. Some people thought that something would have to change in Poland when this demographic peak flooded the labour market in the first years of the 21 st century. The participants of this demographic bulge were thought to be a challenge - with their ambition, education and their youthful revolt. However, when this youth was ready to enter the market, there were no jobs. They will therefore not change this Poland, because they had to leave - they are simply absent. They may come back at some time - with a different mentality, new life models, new technologies, 


\section{The Person and the Challenges \\ 142 Volume 2 (2012) Number 1}

fluent in foreign languages, beaten up and bruised. They may come back, because Europe is not that big. It's a pity they are not here now.

Educational leap

There is no other country in Europe to have made such a big educational leap as in Poland after 1989. Previously $16 \%$ of secondary school graduates went to universities; currently it is almost $60 \%$. In Estonia and Lithuania, the growth is similar but these societies are very small. In Poland it is an educational revolution financed by parental money. The state has not contributed much to it apart from giving consent to private universities and to establishing new fields of study. This success is attributable to the society. University students were hopeful that a master's degrees will open doors for them. Meanwhile, they ended up as "washer-up-ers" in Ireland or England.

The generation of unfulfilled hopes.

It must be remembered that they carry inside sorrow and frustration. Studies indicate that their attitude is "facing the market and turning their back at democracy". The state is hostile to them. If they think about politics they consider it not worthwhile getting involved. Although Polish youth is second only to the Greeks as far as the patriotism is concerned, they state very openly they feel deceived.

The humanities have developed most clearly in this educational leap. Technical studies are less and less popular. The whole of Europe is struggling to develop natural sciences. These studies are more expensive, more difficult to organize and more demanding for students. Young people avoid these studies. They want to study humanities. Why can I say about this? After reading humanities it is more difficult for them to find their place in the society. They must decide who they will be. After technical studies, they find work quickly and establish their direction in life. Many young people graduating in humanities are lost - they do not know what to do.

Who are they? Educated, but without a profession. It does not lead to stability in life. It prolongs a period of searching for social identity ${ }^{6}$.

\section{The teaching of John Paul II in the life of young people}

One may pose a question of how deeply the teaching and activity of John Paul II influenced the spirituality and personality of young people. There are only

${ }^{6}$ K. Pawlina, Nowe pokolenie Polaków a kondycja rodziny, „Studia Slavatoriana Polonica” v. 5 (2011), p. 77-87. 
selected studies related to certain aspects of life of the JP2 Generation. The results of these studies must also be approached with caution, due to another factor. Sociological studies only show one part of the reality. A man, with his feelings and attitudes, is more complex than their sociological description. Secondly, the age of adolescence is a time of rapid changes in a man. Therefore generalisations of the results of these studies of young people after the death of John Paul II are unjustified. Nevertheless, let us look at some of the results.

Answering the question "what, in John Paul II's teaching, is most important to you", the students indicated, in the first place, the Pope's teaching about the family. Then his teaching about love $-27 \%$, and then the Pope's teaching about respect for man $-25 \%$. The teaching about unity, peace, tolerance and ecumenism were also mentioned. The most frequent answers never mentioned the teaching about faith, God, Christ, prayer or the Church.

Generally speaking, one can say that young people do not know the Pope's teaching well. They know John Paul II as a person and they claim that they love him. When asked about their knowledge of the teaching John Paul II, the most frequent answers are more or less like this: "he taught how to love.... it is the most of what he taught; he wanted to show the world how to do it and he succeeded". Or "through his pontificate he showed how deeply you can believe in something and most of all that one can totally devote oneself to it; this is the teaching not written but shown".

The biggest lesson however seems to be the death of John Paul II and the days afterwards. Research has shown that what we could observe in the streets after John Paul II's death was not only a short-lived emotion. It was something more. Young people started to wonder about fundamental issues such as the meaning of life, death, suffering and faith. For many of them this thought resulted in serious personal decisions. We are talking about a change of lifestyle, particularly about relations with people and significant religious awakening. The death of John Paul II for many young people was an occasion to take personal responsibility for their faith which up until now was only treated as a tradition.

Previously, people wondered many times what kind of authority John Paul II represented. Today, we can say that the ultimate quality of his authority was endorsed by the events accompanying his death. . If the ability to induce changes in other people is a measure of authority one must say that given the behaviour of the Polish youth the authority of John Paul II has been empirically proven. It turned out, at the same time, that there is a universe of sensitivity in contemporary man, which gives him a chance to change and develop. A meeting with an authority activates this ability inherent in every man? 
What conclusion can be drawn on the bases of the above? I will say this:

Someone who loves young people has the power to awaken them.

Someone who sets challenges with love becomes their leader.

Someone who does not preach but rather teaches becomes a master?
\end{abstract}

\title{
6. Transformation of the memory of John Paul II
}

What has been written down by historians is often called history. In this way memory is being passed on. But there is a more fundamental dimension of memory - memory lived, experienced. It is all that we have experienced ourselves - in this case we are talking about our countless encounters - as real people - with John Paul II. This memory of ours, the memory of experience is changing into the memory of culture.

The memory which we have inside us about John Paul II is the memory we live by. Young people born at the end of John Paul II's pontificate and later do not have it. They obtain however the memory of culture, i.e. what we tell them about John Paul II. For them it is a second-hand message. We deal with the phenomenon of transforming the memory of John Paul II. How does this process of transformation of memory work? It depends on how we shall talk about John Paul II. Over time things fall apart, words become trivial, a process of forgetting starts.

We keep John Paul II in our heartfelt memories. His teaching is a different issue. It is abundant and, as shown by different kinds of studies, little known. We quote John Paul II, we use his authority and often we use his words when we need to justify something. Sometimes his teachings are used in social and political debates, often selectively and instrumentally. This happens in the circumstances in which the younger generation no longer meets with John Paul II face to face, i.e. when there is no emotional carrier. Thus, instrumentally treated teaching of John Paul II may bring about negative reactions or even weariness. There is too much taken out of context ad hoc, pieces of John Paul II's teaching without comprehensive approach to a given issue. It may blur the picture.

There is a very important insight in one of the poems of Bernadeta KuczeraChachulska referring to John Paul II. She writes:

If

John Paul

${ }^{7}$ K. Pawlina, Dotknięci przez Świętego - młodzi Polacy przeżywaja swoje przebudzenie, „Warszawskie Studia Teologiczne” XIX (2006), p. 265-276. 
is a mark

then who is

$\mathrm{He}$

We were coming to John Paul II because we sensed that he was meeting with God, that he was closed to another world. John Paul II was able to bring it closer to us by his personality. He was a mark of Somebody greater. He does not speak about Him any more. So, the challenge now is how to talk about the Pope, and how not to lose the sight of God who fascinated Blessed John Paul II.

In the Church we talk about yet another kind of memory - the collective memory of saints. We deeply believe that we somehow have a share in the collective wisdom of God's friends. John Paul II is blessed. A Christian will say that it is not enough to talk about him. It is necessary to step into the current of life, as Karol Wojtyła did in the past. What we call the communion of saints is a chance to go back from the level of cultural memory to the space of personal experience. Those who never met John Paul II when he was alive have a chance to meet him now. That is what the communion of saints is about.

\section{Conclusion}

John Paul II said about young people: "You are the hope". Where did this trust in young people come from, since their futures did not seem very bright? Young people are like a meadow in spring time. After winter, there may be a lot of dirt in a meadow, decaying remains, but spring is so powerful that it overcomes everything. The green grass overcomes winter's greyness. Flowers grow even on rotting remains. There is great power and force for good in young people. Therefore, our hopes lie in the youth of today.

\section{Bibliography}

Dolata R., Kosela K., Wiłkomirska A., Zielińska A., Młodzi obywatele. Wyniki międzynarodowych badań młodzieży, Warszawa 2004.

Draguła A., Czy istnieje pokolenie JP2?, „Tygodnik Powszechny” No 24, 16th Octember, 2005, p. 12.

Koralewicz J., Ruszkowski P., Bieliński J., Figiel A., Pokolenie JPII, Dylematy światopogladowe młodzieży, Poznań 2009. 
Nosowski Z., Pokolenie JP2 - pobożna iluzja czy szansa na lepszy świat?, in: T. Szawiela (ed.), Pokolenie JP2 - Przeszłość i przyszłość zjawiska religijnego, Warszawa 2008, p. 122-132.

Pawlina K., Młodzież szkolna o swoich problemach, Warszawa 2010.

Pawlina K., Nowe pokolenie Polaków a kondycja rodziny, „Studia Slavatoriana Polonica” v. 5 (2011), p. 77-87.

Pawlina K., Dotknięci przez Świętego - młodzi Polacy przeżywaja swoje przebudzenie, „Warszawskie Studia Teologiczne” XIX (2006), p. 265-275.

Radiukiewicz A., Pokolenia JP, tożsamość czy kreacja medialna?, in: JP2 pokolenie czy mozaika wartości, Warszawa 2010, p. 179-183.

Sawicka T., Pokolenie JP2. Przeszłość i przyszłość zjawiska religijnego, Warszawa 2008.

Walczak-Duraj D., Wartości i postawy młodzieży polskiej, Łódź 2009.

Worczyński T., Literatura polska po 1939 roku, Warszawa 1995.

Jacy sq młodzi, in: M. Boni (ed.), Młodzi 2011, Warszawa 2011, p. 37-64. 